\title{
Michelangelo's divine goitre
}

\author{
Lennart Bondeson MD PhD Anne-Greth Bondeson MD PhD
}

J R Soc Med 2003;96:609-611

When all things began, goitre already was - at least if we are to believe in Michelangelo's idea of the 'big bang' painted on the ceiling of the Sistine Chapel. In his image of the Separation of Light from Darkness (Figure 1), the Creator shows a clear-cut goitre (Figure 2), a remarkable trait that has passed unnoticed for almost five hundred years.

\section{ANATOMICAL KNOW-HOW}

The fully exposed throat of God as portrayed in the first act of Genesis is painted in such detail that the nodular goitre cannot be just an accidental feature. Michelangelo was a perfectionist in his art, he was obsessed by anatomy, and he was no doubt familiar with the appearance of goitre: a native Tuscan, he spent his youth where goitre was a common sight. ${ }^{1}$ Furthermore, there is good reason to believe that he saw goitre not only on the exterior of people, but also in a deeper, anatomical context. Contemporary biographers explicitly mention that he had his very own dissecting room at the Church of Santo Spirito in Florence, where a friendly prior provided him with corpses for secluded studies of anatomy. ${ }^{2,3}$ It has been suggested that Michelangelo's experience from these autopsies as a teenager inspired him to associate God dividing the Waters from the Earth with a kidney, ${ }^{4}$ and the Creation of Adam with a brain, ${ }^{5}$ when illustrating Genesis on the Sistine ceiling.

\section{Moor anatomy}

Later in life Michelangelo continued to dissect corpses and even played with the thought of publishing a treatise on anatomy together with his physician, the ambitious Realdo Colombo, who advanced to the position of professor and medical consultant to the Vatican. ${ }^{6}$ A daring pupil of the great Vesalius, Colombo made his name in the history of medicine when he clarified the pulmonary circulation by adding vivisection of animals to the study of corpses. ${ }^{7}$ It is less well known that he also contributed to knowledge of anatomy by distinguishing the thyroid gland as a separate organ. ${ }^{8}$ From Michelangelo's ghosted autobiography it

Departments of Pathology and Surgery, Malmö University Hospital, SE-205 02 Malmö, Sweden

Correspondence to: Dr L Bondeson

E-mail: lennart.bondeson@skane.se appears that Dr Colombo, eager to get started with a career-promoting atlas of anatomy, presented his illustrious patient with a most unusual gift - the perfect body of a dead Moor. ${ }^{2}$ The intended collaboration did not materialize, however, and Colombo's textbook De Re Anatomica had to be printed without illustrations by Michelangelo, whose hands were full of other projects. Nevertheless, the good doctor's acquaintance with the artist was successful in another way that deserves a short comment before we focus on the goitre.

\section{THE STONES}

In still existing letters, Michelangelo states that Colombo actually saved his life by treating him with a certain kind of water for kidney stones. ${ }^{9}$ The nature of this stone disease is

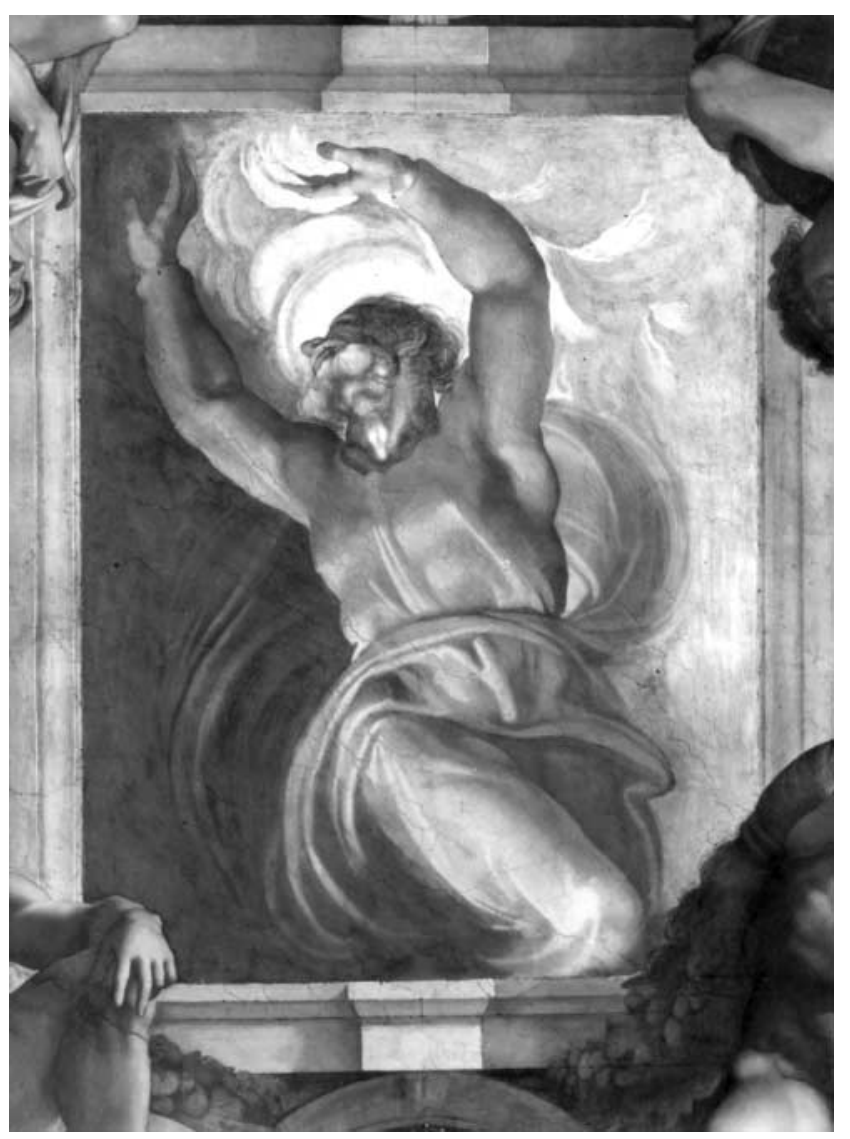

Figure 1 The Creator separating light from darkness. Fresco painted in 1512 on the ceiling of the Sistine Chapel by Michelangelo Buonarroti. (Photograph courtesy of the Vatican Museums) 


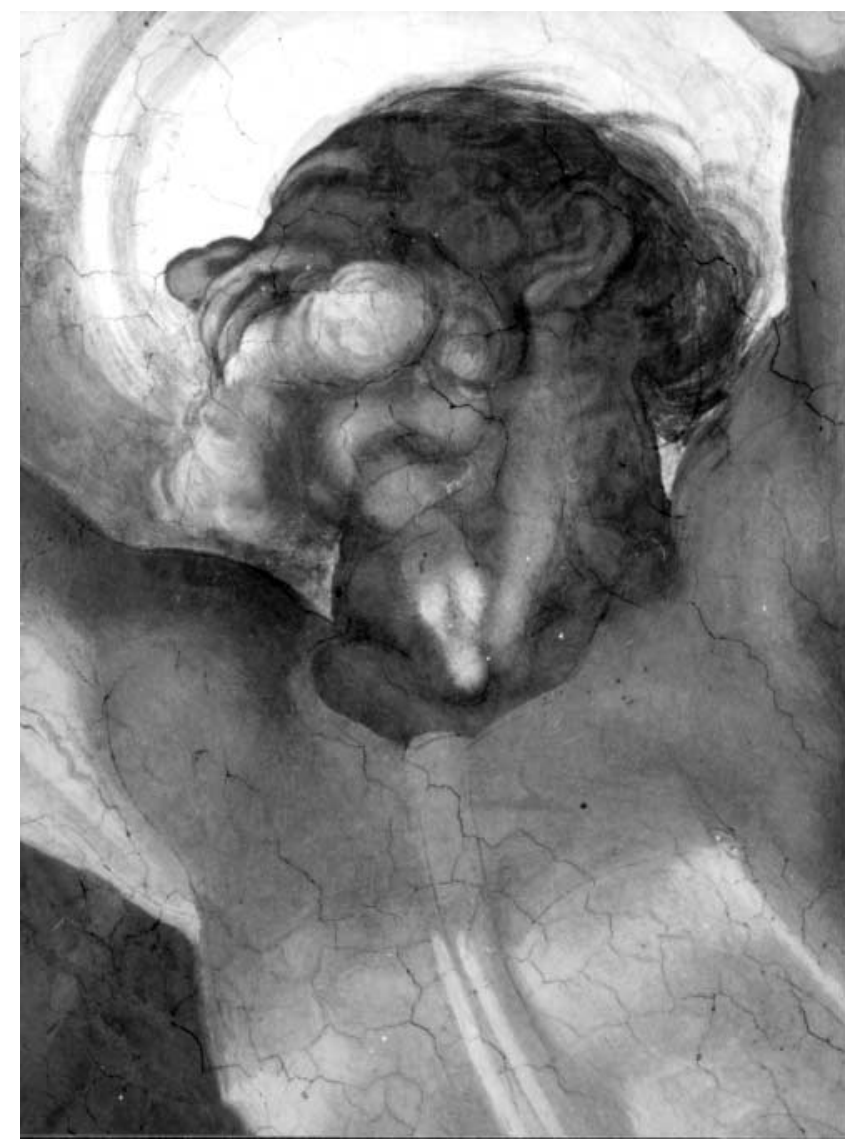

Figure 2 The Creator exhibits a multinodular goitre. (Photograph courtesy of the Vatican Museums)

not known. According to one theory, the artist suffered from gout, a hypothesis based on the look of a knee. Curiously enough, that knee belongs to a philosopherallegedly Heraclitus - in the School of Athens, a fresco painted by Raphael in the Vatican at the same time as Michelangelo was painting the Sistine ceiling. The belief is that Raphael, deeply influenced by what he saw up there, paid homage to the genius of Michelangelo by using the master's appearance to portray the enigmatic Heraclitus, whose lumpy right knee has been presented as a depiction of gonagra. ${ }^{10}$ Considering what will follow, it should be mentioned that the neck of Heraclitus cannot be inspected because of his beard.

\section{GOITRE POETRY}

Returning to the main subject-God's goitre in the Separation of Light from Darkness - two things should be emphasized. First, systematic studies of Michelangelo's artwork from a strictly anatomical point of view have shown that his portrayals were physically accurate, not flawed by inclusion of nonexistent structures for expressive purposes. ${ }^{11}$ Secondly, his knowledge of goitre was more intimate than has been indicated so far. In a satirical poem, written to a friend while struggling with the unwanted task of painting the Sistine ceiling, he describes himself as being afflicted with goitre, illustrating the statement with a caricature in the margin of the manuscript showing his goitrous profile. ${ }^{12}$ In this poem he also compares himself with cats developing goitre from bad water in Lombardy. Although strange, that parallel is appropriate.

\section{PO WATER}

Associations between water and goitre were made long before the days of Michelangelo. The earliest known record dates back to the first century BC, when Vitruvius Pollio, a military engineer and architect serving Julius Caesar, incriminated poor water as the cause of tumidum guttur (swollen throat) in Alpine regions where goitre was endemic. ${ }^{13}$ Another ancient source implying a goitre-water connection is Pliny the Elder, a Roman officer and eager natural historian until his death from curiosity in AD 79 at the great eruption of Vesuvius, which also buried Pompeii. In book XXXVII of his Naturalis Historiae, he stated that peasant women north of the Po wore amber not only as jewellery but also for medical reasons, since the water near the Alps was bad for the throat. ${ }^{13}$ This is quite in line with Michelangelo's poem. North of the River Po, where the plains of Lombardy stretch towards the Alps, is an area where deficiency of iodine in the water caused endemic goitre. ${ }^{1}$

\section{SEASONED SALT}

Michelangelo's strange allusion to feline goitre can be explained as a poetic metaphor, since cat was used in those days as a nickname for peasant. ${ }^{12}$ On the other hand, it is quite likely that Michelangelo saw or heard of goitrous animals, since endemic goitre is by no means restricted to man. ${ }^{1}$ It was indeed the economically devastating occurrences of goitre and hypothyroidism among Montanan piglets, Michiganian sheep, and Pennsylvanian trout that prompted the experiments of 1917 on Ohioan school children that eventually led to use of iodized salt for goitre prevention. ${ }^{13,14}$ After iodized salt was made available by legislation in Italy, the prevalence of goitre in the Tuscan Apennines close to Florence, where Michelangelo grew up, fell from $60 \%$ to $8 \% .{ }^{15}$

\section{DIVINE EMBODIMENT}

One thing remains to be explained — why goitre already was when all things began, in Michelangelo's depiction of Genesis. There is circumstantial evidence indicating that the artist, known as Il Divino, ${ }^{16}$ actually made God in his own goitrous image. ${ }^{17}$ Our own interpretation of this portrayal is that Michelangelo 'signed' his massive achievement - a 
backbreaking fresco of nearly six thousand square feet - by incorporating himself as an embodiment of the Supreme Creator in the final panel to be painted, the Separation of Light from Darkness. Self-esteem of that degree may seem inconceivable but is quite in line with the personality of Michelangelo in those days, judging from psychoanalytic profiles based on his artwork and writings. ${ }^{18,19}$ Even long before the height of what is called his heroic period, ${ }^{16}$ Michelangelo had plenty of self-confidence. When drawing the contract for his Pietà in St Peter's, the 23-year-old artist guaranteed a work that would be the finest marble statue in Rome and a work of art that could not be surpassed by any other living master. ${ }^{20}$ On top of that he signed the finished sculpture in a most conspicuous way by carving, in effect, 'Made by Michelangelo Buonarroti from Florence' in bold letters right across the breast of the Mother of God. ${ }^{21}$

\section{SELF-CREATION}

From what is known about the sequence of events when Michelangelo painted the Sistine ceiling, there is reason to believe that his divine embodiment in the Separation of Light from Darkness was inspired by a rewarding confrontation with his employer, the violent and impatient 'Warrior Pope' Julius II. The Pope had beaten him for not working fast enough, and Michelangelo-fittingly named after the 'Warrior Angel' (Revelation 12:7) - answered with an unheard-of effrontery, threatening to leave the job unfinished if the Pope did not apologize. After some negotiating, this ultimatum brought Michelangelo not only apologies but also a substantial peace offering, reckoned in the 1970s at some US\$25000 of purchasing power. ${ }^{2}$ Considering the close and complex personal bonds tying Michelangelo and Pope Julius to each other-including a megalomaniac folie à deux and a substitute father-son relationship with a strain of sadomasochism ${ }^{18,19}$ - this remarkable clash and the artist's subsequent self-image as the goitrous Almighty constitute a striking illustration of the psychological process known as 'sculpting'. This process, whereby an ideal self is fashioned by means of interaction with a close partner, has indeed become known as the Michelangelo phenomenon. ${ }^{22}$

\section{REFERENCES}

1 Kelley FC, Snedden WW. Prevalence and geographical distribution of endemic goitre. In: World Health Organization Monograph Series No. 44: Endemic Goitre. Geneva: WHO, 1960:27-233

2 Condivi A. The Life of Michelangelo (transl A Sedgwick Wohl, edited by H Wohl). London: Phaidon, 1976:17, 59, 99, 147

3 Vasari G. The Lives of the Artists (transl J Conaway Bondanella, P Bondanella). Oxford: Oxford University Press, 1998:422

4 Eknoyan G. Michelangelo: art, anatomy, and the kidney. Kidney Int 2000;57:1190-201

5 Meshberger FL. An interpretation of Michelangelo's Creation of Adam based on neuroanatomy. JAMA 1990;264:1837-41

6 Eknoyan G, DeSanto NG. Realdo Colombo (1516-1559): a reappraisal. Am J Nephrol 1997;17:261-8

7 Fye WB. Profiles in cardiology: Realdo Colombo. Clin Cardiol 2002;25:135-7

8 Langer P. History of goitre. In: World Health Organization Monograph Series No 44: Endemic Goitre. Geneva: WHO, 1960:16

9 Steinberg L. Michelangelo and the doctors. Bull Hist Med 1982;56:543-53

10 Espinel CH. Michelangelo's gout in a fresco by Raphael. Lancet 1999;354:2149-51

11 Elkins J. Michelangelo and the human form: his knowledge and use of anatomy. Art Hist 1984;7:176-86

12 Saslow JM. The Poetry of Michelangelo: An Annotated Translation. New Haven: Yale University Press, 1991:70-2

13 Merke F. History and Iconography of Endemic Goitre and Cretinism. Berne: Hans Huber, 1984:22-8, 92-100

14 Marine D, Kimball OP. The prevention of simple goiter in man. J Clin Lab Med 1917;3:40-8

15 Aghini-Lombardi F, Pinchera A, Antonangeli L, et al. Iodized salt prophylaxis of endemic goiter: an experience in Toscana (Italy). Acta Endocrinol (Copenh) 1993;129:497-500

16 de Tolnay C. The historic and artistic personality of Michelangelo. In: The Complete Work of Michelangelo, Vol I. London: Macdonald, 1966: $7-71$

17 Bondeson L, Bondeson A-G. The Creator separating light from darkness: a 'new' self-portrait of Michelangelo? Konsthistorisk Tidskrift/ Journal of Art History 2001;70:189-92

18 Liebert RS. Michelangelo: A Psychoanalytic Study of His Life and Images. New Haven: Yale University Press, 1983:140-64

19 Oremland JD. Michelangelo's Sistine Ceiling: a psychoanalytic study of creativity. In: Pollock GH, ed. Applied Psychoanalysis Monograph Series, No. 2. Madison: International Universities Press, 1989:95-130

20 De Feo F. Biographical note. In: The Complete Work of Michelangelo, Vol II. London: Macdonald, 1966:566-7

21 Goldscheider L. Michelangelo: Paintings, Sculptures, Architecture, 4th (complete) edn. London: Phaidon, 1963:10, plate 13

22 Drigotas SM, Rusbult CE, Wieselquist J, Whitton SW. Close partner as sculptor of the ideal self: behavioral affirmation and the Michelangelo phenomenon. J Pers Soc Psychol 1999;77:293-323 